\title{
Relationship Satisfaction Pada Mahasiswa Yang Berpacaran Ditinjau Dari Perilaku Phubbing
}

\author{
Farida Novitasari ${ }^{1}$, Yuarini Wahyu Pertiwi ${ }^{1, *}$, Tiara Anggita Perdini ${ }^{2}$ \\ ${ }^{1}$ Fakultas Psikologi; Universitas Bhayangkara Jakarta Raya; Jl. Perjuangan 081, Marga Mulya, \\ Bekasi Utara; 02188955882/ +622188955871; e-mail: faridans23@gmail.com, \\ yuarini.wp@dsn.ubharajaya.ac.id \\ 2 Fakultas Psikologi; Universitas Persada Indonesia YAl; Jl. Pangeran Diponegoro No.74, \\ Kenari, Kec. Senen, Kota Jakarta Pusat, 0213926000; e-mail: tiaraanggitaperdini@gmail.com \\ * Korespondensi: e-mail: yuarini.wp@dsn.ubharajaya.ac.id
}

Submitted: 17/11/2021; Revised: 19/11/2021; Accepted: 06/12/2021; Published: 31/12/2021

\begin{abstract}
Relationship satisfaction is an interpersonal evaluation and the main assessment in a relationship by involving thoughts and feelings, where in this study the feeling in question is satisfaction. Individuals who feel relationship satisfaction will have better mental and physical health and have the readiness to change bad behavior for the better. Relationship satisfaction can be influenced by the quality of communication. As technology develops and the COVID-19 pandemic changes the quality of communication changes, giving rise to phubbing behavior. The purpose of this study was to determine whether phubbing behavior was able to predict relationship satisfaction in dating students at Bhayangkara University, Jakarta Raya. The research method used is quantitative-causality with convenience sampling technique. The results showed that phubbing behavior was able to predict relationship satisfaction significantly because $p=0.000$ or $p<0.05$. Based on these results, it can be concluded that the alternative hypothesis $(\mathrm{Ha})$ is accepted and the null hypothesis $(\mathrm{HO})$ is rejected, which means that phubbing behavior is able to predict relationship satisfaction in students who are dating at Bhayangkara University, Jakarta Raya. The next research is expected to be able to examine other factors and increase the literature so that the research becomes better.
\end{abstract}

Keywords: Dating, Phubbing, Relationship Satisfaction, Student

\begin{abstract}
Abstrak
Relationship satisfaction adalah evaluasi interpersonal dan penilaian utama dalam sebuah hubungan dengan melibatkan pikiran dan perasaan, dimana dalam penelitian ini perasaan yang dimaksud adalah kepuasan. Individu yang merasakan relationship ssatisfaction akan memiliki kesehatan mental dan fisik yang lebih baik serta memiliki kesiapan untuk mengubah perilaku buruk menjadi lebih baik. Relationship satisfaction dapat dipengaruhi oleh kualitas komunikasi. seiring berkembangnya teknoogi dan adanya pandemi covid-19 kualitas komunikasi berubah, sehingga menimbulkan perilaku phubbing. Tujuan penelitian ini adalah untuk mengetahui apakah perilaku phubbing mampu memprediksi relationship satisfaction pada mahasiswa yang berpacaran di universitas bhayangkara jakarta raya. Metode penelitian yang digunakan adalah kuantitatif-kausalitas dengan teknik sampling convenience. Hasil penelitian menunjukan bahwa perilaku phubbing mampu memprediksi relationship satisfaction secara signifikan karena $p=0,000$ atau $p<0,05$. Berdasar hasil tersebut maka dapat disimpulkan bahwa hipotesis alternative $(\mathrm{Ha})$ diterima dan Hipotesis $\mathrm{Nol}(\mathrm{HO})$ ditolak, yang berarti bahwa perilaku phubbing mampu memprediksi relationship satisfaction pada mahasiswa yang berpacaran di universitas bhayangkara jakarta raya. Penelitian berikutnya diharapkan dapat meneliti faktor lain dan memperbanyak literatur agar penelitian menjadi lebih baik.
\end{abstract}

Kata kunci: Berpacaran, Phubbing, Relationship Satisfaction, Mahasiswa 


\section{Pendahuluan}

Dewasa awal adalah masa dimana didalam diri sebagian besar individu terjadi perubahan penting yang terkait dengan eksplorasi identitas, khususnya yang berkaitan dengan relasi romantis (Santrock, 2012). Menurut Erikson (dalam Feist \& Feist, 2010) dewasa awal dimulai dari sekitar usia 19 hingga 30 tahun. Berdasar kepada hal tersebut, maka pada penelitian ini peneliti fokus kepada usia dewasa awal karena mahasiswa merupakan individu yang rata rata berusia 19-30 tahun. Individu usia dewasa awal sedang berada pada fase keintiman vs keterasingan. Keintiman adalah kemampuan untuk meleburkan identitas seseorang dengan orang lain dengan melibatkan kompromi, pengorbanan dan komitmen dalam hubungan yang setara. Misalnya dengan menjalani sebuah hubungan romantis yang dikenal sebagai istilah pacaran (Safitri \& Arianti, 2019).

Pasangan yang menjalani hubungan romantis atau berpacaran perlu untuk berkomunikasi dan bertemu untuk menghabiskan waktu bersama, karena dengan adanya kedekatan fisik dan melakukan komunikasi secara langsung atau saling bertemu dapat merasakan keintiman yang akan membuat pasangan lebih merasakan kebahagiaan dan dapat dengan mudah mempertahankan hubungan (Kurniati, 2015). Akan tetapi, pada Akhir tahun 2019 hingga sekarang muncul sebuah virus yang dapat menyerang sistem pernapasan, pneumonia akut hingga menyebabkan kematian, yaitu virus corona atau covid-19 (Dani \& Mediantara, 2020). Covid-19 merupakan sebuah virus yang dapat menular dari manusia ke manusia lainnya, sehingga mengharuskan semua manusia untuk melakukan physical distancing yang mengakibatkan pasangan untuk mengurangi komunikasi secara langsung dan mengganti proses komunikasi menjadi komunikasi secara online menggunakan smartphone (Rahma, 2020).

Menurut laporan International Data Corporation (IDC) sejak adanya pandemi covid-19 pertumbuhan penggunaan smartphone meningkat sebesar 49\% (Dewi, 2020). Peningkatan penggunaan smartphone diakibatkan karena adanya perubahan proses komunikasi akibat pandemi covid-19 yang membuat semua orang harus lebih sering menggunakan smartphone untuk kebutuhan sehari-hari seperti untuk memberi kabar kepada orang lain, bekerja dari rumah hingga belajar secara online dirumah (Retalia, 2020).

Sehingga ketika pasangan saling bertemu secara langsung tidak heran jika salah satu dari mereka lebih sibuk dengan smartphone dan mengabaikan pasangan, hal ini dinamakan dengan istilah phubbing. Phubbing adalah suatu bentuk pengabaian terhadap orang lain karena seseorang menggunakan smartphonenya ketika sedang berkomunikasi secara langsung dengan orang lain (Chotpitayasunondh \& Douglas, 2018). Lebih lanjut Chotpitayasunondh \& Douglas (2018) juga menjelaskan bahwa dalam proses komunikasi secara langsung seseorang yang melakukan perilaku phubbing disebut dengan "Phubber" dimana Phubber diartikan sebagai orang yang memulai melakukan phubbing dengan lawan bicara dan mengabaikan lawan bicara karena lebih fokus dengan smartphone sedangkan yang menjadi korban dari perilaku phubbing atau orang yang menerima perilaku phubbing dari orang lain disebut sebagai 
"phubbee". Dimana dalam penelitian ini akan lebih fokus kepada para pelaku phubbing atau yang disebut sebagai phubber. Alasannya adalah karena pada penelitian ini mengangkat gejala variabel dari phubbing sebagai tindakan dari phubber dimasa yang serba online ini.

Menurut phubbber, phubbing adalah hal lumrah dan merupakan hal wajar yang biasa terjadi dan dilakukan banyak orang di era modern yang serba menggunakam smatrphone. Tanpa sengaja phubber melakukan hal tersebut karena ada hal penting yang harus ia selesaikan dengan smartphonenya walaupun dalam konteks sedang berkomunikasi dengan pasangan (Pratiwi, 2020). Menurut Utami \& Rachmawati (2015) Pasangan yang menjalani hubungan romantis atau berpacaran harus dapat memahami dan menghargai satu sama lain, mengerti apa yang harus dilakukan dan saling memberikan kasih sayang, percaya satu sama lain sehingga dapat memunculkan kepuasan dalam hubungan atau relationship satisfaction. Selanjutnya, Menurut Hendrick (dalam Pawiyataningrum, 2019) Relationship satisfaction adalah evaluasi secara menyeluruh yang dilakukan oleh individu terhadap hubungan yang sedang dijalani dengan pasangannya yang berkaitan pada perasaan dan pikiran yang merupakan salah satu penilaian utama dalam sebuah hubungan.

Individu yang merasa puas dengan hubungannya atau merasakan relationship satisfaction akan memiliki kesehatan mental yang lebih baik, lebih siap dalam menghadapi masa depan dan memiliki kesiapan yang tinggi untuk mengubah perilaku buruk menjadi lebih baik demi pasangannya (Khaddaouma et al., 2016). Selain itu, individu yang merasakan relationship satisfaction akan merasakan konteks hidup secara positif dan memberikan manfaat bagi kesehatan mental yang berupa adanya kebahagiaan dan kesehatan fisik (Whisman, Uebelacker, \& Settles, 2010).

Banyaknya dampak positif yang bisa didapatkan dari relationship satisfaction menyebabkan pentingnya untuk mencari tahu apa saja yang berperan dalam tercapainya relationship satisfaction, khususnya pada mahasiswa yang sedang berpacaran. Jika relationship satisfaction tidak didapatkan, dapat berdampak pada kesehatan fisik, seperti menurunnya sistem imun (Kiecolt-Glaser \& Wilson, 2017) dan kesehatan mental seperti mengalami kecemasan serta gejala depresi (Di Bello, Preddy, Overup, \& Neighbors, 2017).

Relationship Satisfaction dapat dipengaruhi oleh beberapa hal, salah satunya adalah phubbing yang merupakan gaya baru dalam berkomunikasi. Salah satu faktor yang mempengaruhi relationship satisfaction seperti yang dikemukakan oleh Miller \& Tedder (2011) yaitu kualitas komunikasi. Kualitas komunikasi yang baik antar pasangan seperti berbagi komunikasi yang terbuka, menjadi pendengar yang baik terhadap pasangan, memiliki interaksi yang menyenangkan akan memberikan kontribusi bagi kepuasan hubungan atau relationship satisfaction. Pasangan yang memiliki kualitas komunikasi yang baik akan memiliki tingkat kepuasan hubungan yang tinggi dibanding dengan pasangan dengan kualitas komunikasi yang rendah atau tidak baik. Perilaku phubbing yang di maksud dalam penelitian ini merupakan bagian dari kualitas komunikasi. Adapun bentuk komunikasi yang diinginkan phubber dengan pasangan adalah saling mengerti dan tidak mengganggu ketika sedang ada kesibukan (Arnani, 
2019). Menurut Pratiwi (2020) seseorang tidak bisa memaksa orang lain untuk berperilaku sesuai yang di inginkan, termasuk tidak menggunakan smartphone saat bersama pasangan karena manusia memiliki hak berperilaku sesuai dengan keinginan dan kenyamanannya. Dahulu jika manusia ingin berkomunikasi, menyampaikan pesan atau informasi kepada orang lain harus bertemu dan bertatap muka secara langsung. Beda hal dengan saat ini, hanya hitungan detik informasi yang ingin disampaikan kepada orang lain dapat langsung tersampaikan dengan adanya media baru yang merupakan suatu sarana yang baru hadir. Hal ini berarti dengan semua perkembangan teknologi yang ada, media baru hadir untuk memenuhi kebutuhan informasi masyarakat, yaitu smartphone (Yashinta, 2019).

Berdasar hasil wawancara peneliti kepada 10 orang mahasiswa Univerista Bhayangkara Jakarta Raya bahwa hingga saat ini semua informan masih menjadi pelaku phubbing/phubber ketika bersama pasangan. Informan mengatakan bahwa Phubbing dilakukan karena berbagai alasan, diantaranya karena untuk membalas chatting orang lain, menerima panggilan/telpon, melihat sosial media, mengabadikan momen dengan mengunggahnya ke sosial media, bermain game, serta melakukan pekerjaan dan perkuliahan secara online.

Tiga dari sepuluh informan mengatakan bahwa pasangan sangat mempermasalahkan jika ia menjadi phubber dan hal tersebut dapat memicu adanya konflik. Hal ini sejalan dengan penelitian yang dilakukan oleh Pratiwi (2020) dimana hasil penelitian ini adalah perilaku phubbing yang dilakukan oleh pasangan adalah tindakan yang sangat meresahkan, phubbing juga dapat merusak keharmonisan dalam sebuah hubungan dan memicu adanya konflik.

Sedangkan tujuh lainnya mengatakan bahwa pasangan tidak mempermasalahkan dan memberikan kebebasan kepada informan untuk menggunakan smartphonenya ketika bertemu atau menjadi phubber dengan alasan pada saat pandemi seperti ini, banyak aktivitas yang dilakukan secara online seperti kuliah dan bekerja sehingga pasangan dapat mengerti dan menganggap bahwa perilaku phubbing yang dilakukan terhadapnya adalah hal yang wajar. Hal ini sejalan dengan penelitian yang dilakukan oleh Rosdiana \& Hastutiningtyas (2020) dimana hasil dari penelitian ini adalah phubbing merupakan tindakan yang wajar dilakukan karena informasi yang didapat dari smartphone harus didahulukan jika terkait dengan tugas dan aktivitas yang penting.

Berdasar hasil wawancara diatas juga menjelaskan bahwa pasangan yang tidak mempermasalahkan jika informan menjadi phubber saat bersama, membuat informan lebih bahagia, merasa senang dan yakin dengan pasangannya karena merasa pasangan sangat mengerti dirinya dan kesibukannya. Sedangkan pasangan yang membatasi dan mempermasalahkan jika informan menjadi phubber membuat informan merasa bosan, merasa pasangan banyak mengatur tentang dirinya hingga malas bertemu dengan pasangan.

Hal ini sejalan dengan berita yang di lansir oleh Wima (2015) bahwa sebuah hubungan dapat berhasil jika keduanya memiliki porsi yang seimbang dalam menjalani hubungan. Seperti, tidak memberikan banyak aturan kepada pasangan, memberikan kebebasan berperilaku 
termasuk menggunakan smartphone saat bersama, dan tidak mendominasi pasangan akan membuat pasangan lebih bahagia dan tidak merasa bosan.

Hubungan pacaran yang dijalani dengan banyaknya aturan dari pasangan, tidak memberikan kebebasan terhadap pasangan, tidak saling mendukung dan tingginya dominasi dari pasangan akan membuat individu sulit untuk merasakan relationship satisfaction, oleh karena itu tidak banyak memberikan aturan kepada pasangan adalah hal yang penting (Yu, Branje, Keijers, \& Meeus, 2014).

Lebih lanjut, informan juga menjelaskan bahwa rata-rata durasi menggunakan smartphone dalam satu hari adalah 7 sampai 8 jam. Hal ini sejalan dengan data laporan tahunan App Annie (2020) yang bertajuk "State of mobile 2020" rata rata waktu yang dihabiskan orang Indonesia dalam menggunakan smartphone mencapai lebih dari 4 jam perhari selama tahun 2019. Data tersebut menunjukan bahwa Indonesia merupakan Negara yang menggunakan smartphone dengan intensitas yang cukup tinggi. Selain itu, informan mengaku puas dengan hubungannya dengan memberikan nilai 6-8 dari skala 1-10 untuk penilaian terhadap kepuasan hubungannya atau relationship satisfaction.

Penelitian terdahulu dilakukan oleh Cizmeci (2017) hasil dari penelitian ini adalah seorang pelaku phubbing atau phubber tetap meraasakan kepuasan dalam hubungan atau relationship satisfaction dimana phubbing merupakan perilaku yang wajar dan dapat diterima dalam kehidupan sosial. Berdasarkan fenomena yang ada, perilaku phubbing dan relationship satisfaction menarik perhatian peneliti sehingga peneliti tertarik untuk mengangkat penelitian yang berjudul "Perilaku Phubbing Sebagai Prediktor Relationship Satisfaction pada mahasiswa yang berpacaran di Universitas Bhayangkara Jakarta Raya"

\section{Metode Penelitian}

Penelitian ini bersifat kausalitas dengan metode kuantitatif. Penelitian kuantitatif bertujuan untuk membuktikan hipotesis dengan proses analisis melalui metode statistika sehingga data yang dihasilkan dalam penelitian kuantitatif berbentuk angka/skor (Periantalo, 2016). Sedangkan kausalitas adalah penelitian yang bersifat sebab akibat dengan independen variabel sebagai variabel yang mempengaruhi dan dependen variabel sebagai variabel yang dipengaruhi (Sugiyono, 2016). Sampel pada penelitian ini berjumlah 100 responden, dengan kriteria sebagai berikut: (1) Berusia 19-30 tahun, (2) Sedang menjalani hubungan berpacaran dan (3) Pelaku phubbing. teknik sampling yang digunakan dalam penelitian ini adalah Non probability sampling dengan jenis Convenience Sampling. Convenience sampling, yaitu peneliti hanya mengambil sampel pada orang-orang yang memenuhi kriteria tertentu, seperti kemudahan aksesibilitas, kedekatan geografis, ketersediaan pada waktu tertentu, atau kesediaan dalam berpartisipasi untuk tujuan penelitian (Etikan, Musa, \& Alkassim, 2017).

Teknik analisis yang digunakan untuk mengetahui apakah perilaku phubbing mampu memprediksi relationship satisfaction pada mahasiswa yang berpacaran di universitas bhayangkara jakarta raya dengan teknik analisis regresi sederhana . 


\section{Hasil dan Pembahasan}

\subsection{Sub Bab 1}

Responden dalam penelitian ini berjumlah 100 mahasiswa Universitas Bhayangkara Jakarta Raya. Penyebaran skala penelitian dilakukan menggunakan Google form karena seluruh mahasiswa Universitas Bhayangkara Jakarta Raya sedang melakukan perkuliahan secara daring akibat adanya pandemi covid-19. Berikut adalah deskripsi responden :

Tabel 1. Deskripsi Responden

\begin{tabular}{|c|c|c|c|}
\hline kelompok & kategori & Jumlah & Presentasi \\
\hline Jenis & Laki-Laki & 37 & $37 \%$ \\
\hline Kelamin & Perempuan & 63 & $63 \%$ \\
\hline \multirow[t]{7}{*}{ Usia } & 19 Tahun & 9 & $9 \%$ \\
\hline & 20 Tahun & 19 & $19 \%$ \\
\hline & 21 Tahun & 43 & $43 \%$ \\
\hline & 22 Tahun & 16 & $16 \%$ \\
\hline & 23 Tahun & 6 & $6 \%$ \\
\hline & 24 Tahun & 4 & $4 \%$ \\
\hline & 30 Tahun & 3 & $3 \%$ \\
\hline \multirow[t]{7}{*}{ Fakultas } & Psikologi & 36 & $36 \%$ \\
\hline & Teknik & 9 & $9 \%$ \\
\hline & IImu Komputer & 12 & $12 \%$ \\
\hline & Ekonomi\&Bisnis & 10 & $10 \%$ \\
\hline & IImu Komunikasi & 13 & $13 \%$ \\
\hline & Hukum & 12 & $12 \%$ \\
\hline & IImu Pendidikan & 8 & $8 \%$ \\
\hline \multirow[t]{5}{*}{ Semester } & 1 & 5 & $5 \%$ \\
\hline & 3 & 12 & $12 \%$ \\
\hline & 5 & 24 & $24 \%$ \\
\hline & 7 & 52 & $52 \%$ \\
\hline & 9 & 7 & $7 \%$ \\
\hline Lama & $\begin{array}{lll}\text { Kurang } & \text { dari } & 1\end{array}$ & 28 & $28 \%$ \\
\hline Hubungan & tahun & & \\
\hline \multirow[t]{3}{*}{ Berpacaran } & Lebih dari 1 tahun & 47 & $47 \%$ \\
\hline & Lebih dari 3 tahun & 15 & $15 \%$ \\
\hline & Lebih dari 5 tahun & 10 & $10 \%$ \\
\hline
\end{tabular}

Sumber: Hasil Penelitian (2022)

\subsection{Uji Asumsi}

Berdasarkan hasil uji normalitas diperolwh nilai signifikansi (p) sebesar 0,084 pada skala relationship satisfaction dan sebesar 0.200 untuk skala perilaku phubbing. Hal ini menunjukan bahwa $p>0,05$ yang berarti bahwa kedua variabel dalam penelitian ini terdistribusi secara normal. Berdasarkan hasil uji linieritas diperoleh nilai signifikansi deviation from linearity 
sebesar $0,000(p \leq 0,05)$ dapat diartikan bahwa variabel relationship satisfaction dan perilaku phubbing memiliki hubungan yang linier. Selanjutnya pada uji homogenitas diperoleh nilai signifikansi sebesar $0,193(p \geq 0,05)$ dengan begitu dapat disimpulkan bahwa kedua variabel dalam penelitian ini memiliki varian yang sama (homogen).

Tabel 2. Hasil Uji Asumsi

\begin{tabular}{cccc} 
Variabel & Normalitas & Linieritas & Homogenitas \\
\hline $\begin{array}{ccc}\text { Relationship } \\
\text { Satisfaction }\end{array}$ & 0.084 & 0.000 & 0.193 \\
\hline $\begin{array}{c}\text { Perilaku } \\
\text { Phubbing }\end{array}$ & 0.200 & & \\
\hline
\end{tabular}

Sumber: Hasil Penelitian (2022)

\subsection{Uji Kategorisasi}

Responden dalam penelitian ini berjumlah 100 mahasiswa Universitas Bhayangkara Jakarta Raya. Penyebaran skala pe Relationship satisfaction pada mahasiswa yang berpacaran di Universitas Bhayangkara Jakarta Raya dalam penelitian ini diukur menggunakan skala relationship satisfaction yang terdiri dari 18 aitem dengan skor tertinggi 5 dan skor terendah 1 dengan mean empirik sebesar 66,16 . Hasilnya adalah sebagai berikut:

Tabel 3. Kategorisasi Relationship Satisfaction

\begin{tabular}{cccc}
\hline Variabel & Normalitas & Jumlah Subjek & Presentase \\
\hline Sangat Rendah & $\leq 55,62$ & 5 & $5 \%$ \\
\hline Rendah & $\leq 62,65$ & 26 & $26 \%$ \\
\hline Sedang & $\leq 69.67$ & 37 & $37 \%$ \\
\hline Tinggi & $\leq 76,7$ & 26 & $26 \%$ \\
\hline Sangat Tinggi & $>76,7$ & 6 & $6 \%$
\end{tabular}

Sumber: Hasil Penelitian (2022)

Sedangkan variabel Perilaku phubbing dalam penelitian ini di ukur menggunakan skala perilaku phubbing yang terdiri dari 13 aitem dengan skor tertinggi 5 dan skor terendah 1 dengan mean empirik sebesar 45,61. Hasilnya adalah sebagai berikut :

Tabel 4. Kategorisasi Perilaku Phubbing

\begin{tabular}{cccc}
\hline Variabel & Normalitas & Jumlah Subjek & Presentase \\
\hline Sangat Rendah & $\leq 32,76$ & 6 & $6 \%$ \\
\hline Rendah & $\leq 41,33$ & 21 & $21 \%$ \\
\hline Sedang & $\leq 49,89$ & 43 & $43 \%$ \\
\hline Tinggi & $\leq 58,46$ & 23 & $23 \%$ \\
\hline Sangat Tinggi & $>58,46$ & 7 & $7 \%$
\end{tabular}

Sumber: Hasil Penelitian (2022)

\subsection{Uji Korelasi}

Uji korelasi yang digunakan dalam penelitian ini adalah dengan uji korelasi person product moment untuk mengetahui seberapa besar hubungan antara relationship satisfaction 
dengan perilaku phubbing dan ada atau tidaknya hubungan antara relationship satisfaction dan perilaku phubbing. Hasilnya adalah sebagai berikut:

Tabel 5. Hasil Uji Korelasi Pearson Product Moment

\begin{tabular}{cccc}
\hline Variabel & Koefisien korelasi & Signifikasi & $\begin{array}{c}\text { Jumlah } \\
\text { Subjek }\end{array}$ \\
\cline { 1 - 1 } Relationship Satisfaction & 0.603 & 0.000 & 100
\end{tabular}

Sumber: Hasil Penelitian (2022)

\subsection{Uji Regresi Linier Sederhana}

Peneliti melakukan uji regresi menggunakan uji regresi linier sederhana, Uji regresi linier sederhana dilakukan untuk mengukur besarnya pengaruh independen variabel terhadap dependen variabel. Hasil yang diperoleh adalah sebagai berikut:

Tabel 6. Hasil Uji Regresi Linier Sederhana

\begin{tabular}{cccc}
\hline Variabel & Signifikansi & $\begin{array}{c}\text { Persamaan } \\
\text { Regresi }\end{array}$ & R Square \\
\hline Relationship Satisfaction & 0.000 & 0.495 & 0.363
\end{tabular}

Sumber: Hasil Penelitian (2022)

Berdasarkan hasil analisis regresi di atas dapat diketahui bahwa perilaku phubbing mampu memprediksi relationship satisfaction secara signifikan dengan nilai $F=55,921$ dan $p=0,000$ atau $p<0,05$. Berdasar hasil tersebut maka dapat disimpulkan bahwa hipotesis alternative $(\mathrm{Ha})$ dalam penelitian ini diterima dan Hipotesis Nol ditolak, yang berarti bahwa perilaku phubbing mampu memprediksi relationship satisfaction pada mahasiswa yang berpacaran di universitas bhayangkara jakarta raya. Model persamaan regresi linier dilihat dari nilai koefisien konstanta dan koefisien regresi yang dapat dilihat pada tabel unstandardized coefficient. Rumus persamaan regresi linier sederhana adalah $\mathrm{Y}=\mathrm{a}+\mathrm{bX}$, maka persamaan regresinya adalah $Y=43,585+0,495 X$. Artinya setiap kenaikan $1 \%$ pada perilaku phubbing menaikkan relationship satisfaction sebessar 0,495. Berdasarkan tabel diatas juga dapat dilihat bahwa nilai $R$ square adalah 0,363 dapat diartikan bahwa perilaku phubbing mempengaruhi relatonship satisfaction sebesar $36,3 \%$ sedangkan sisanya dipengaruhi oleh faktor lain yang tidak diteliti.

\subsection{Pembahasan}

Berdasarkan hasil penyebaran kuesioner diperoleh 100 responden. Berdasarkan jenis kelamin didominasi oleh perempuan dengan presentase sebesar $63 \%$, berdasarkan usia di dominasi oleh responden dengan usia 21 tahun sebanyak 43\%, berdasarkan fakultas di dominasi oleh fakultas psikologi dengan $36 \%$, berdasarkan semester pada penelitian ini di dominasi oleh responden semester 7 dengan presentase sebesar $52 \%$ dan berdasarkan lamanya hubungan berpacaran di dominasi oleh responden dengan durasi pacaran lebih dari 1 tahun dengan presentase $47 \%$. 
Berdasarkan uji kategorisasi dengan menggunakan mean empirik hasil penelitian ini menunjukan sebanyak $5 \%$ responden berada pada kategorisasi sangat rendah. Ssebanyak $26 \%$ responden berada pada kategorisasi yang rendah. Kemudian Sebanyak 37\% responden berada pada kategorisasi sedang. sebanyak $26 \%$ responden berada pada kategorisasi tinggi. Selanjutnya sebanyak $6 \%$ responden berada pada kategori relationship satisfaction yang Sangat tinggi. Selanjutnya pada kategorisasi perilaku phubbing phubbing sebanyak 6\% responden berada pada kategori Sangat rendah, Sebanyak 21\% responden berada pada kategorisasi rendah, Kemudian sebanyak $43 \%$ responden dalam penelitian ini berada dalam kategori sedang, Sebanyak 23\% merupakan responden yang termasuk dalam kategori Tinggi dan sebanyak $7 \%$ merupakan responden dengan kategori perilaku phubbing sangat tinggi.

Guna melakukan uji korelasi, berdasarkan hasil uji asumsi dapat dilihat bahwa data terdistribusi normal, memiliki hubungan yang linier dan memiliki varian yang sama (homogen), maka untuk melakukan uji korelasi dalam penelitian ini menggunakan teknik statistik parametrik dengan korelasi product moment pearson dimana hal ini karena memenuhi syarat perhitungan statistic (Priyatno, 2012). Berdasarkan hasil penelitian yang telah dilakukan dengan teknik korelasi product moment pearson menunjukan bahwa perilaku phubbing dan relationship satisfaction memiliki nilai koefisien korelasi sebesar $0,603^{* *}$ dengan taraf signifikansi sebesar 0,000 yang berarti $p<0,05$. Hal tersebut menunjukan bahwa ada hubungan positif antara perilaku phubbing dengan relationship satisfaction. Semakin tinggi perilaku phubbing maka semakin tinggi juga relationship satisfaction.

Hasil penelitian ini sejalan dengan penelitian yang dilakukan oleh Cizmeci (2017) yang berjudul "Disconnected, Though Satisfied: Pphubbing Behavior and Relationship Satisfaction" hasil dari penelitian ini adalah seorang pelaku phubbing atau phubber tetap meraasakan kepuasan dalam hubungan atau relationship satisfaction karena phubbing merupakan perilaku yang wajar dan dapat diterima dalam kehidupan sosial. Berdasarkan penelitian yang dilakukan oleh Servies (2012), juga mendapatkan hasil bahwa dengan adanya gangguan perangkat teknologi yang menyebabkan terjadinya perilaku phubbing tidak berdampak negatif terhadap relationship satisfaction. Berdasarkan perspektif Hall, Baym, \& Miltner (2014) Phubbing merupakan hal yang tidak terhindarkan terlepas dari puas atau tidaknya sebuah hubungan. Individu akan melakukan perilaku phubbing karena melihat di lingkungan sekelilingnya atau sebagian besar individu juga melakukan phubbing sehingga individu melihatnya sebagai hal yang dapat diterima secara sosial (Chotpitayasunondh \& Douglas, 2016). Oleh karena itu tindakan yang biasa dilakukan oleh pasangan dengan menjadi phubber tidak membuat mereka merasa bahwa kualitas komunikasi dengan pasangannya menurun atau bahkan menjadi rusak.

Selanjutnya dalam melakukan uji hipotesis, peneliti melakukan uji regresi linier sederhana untuk melihat apakah perilaku phubbing dapat memprediksi relationship satisfaction dan ingin mengetahui seberapa besar pengaruh perilaku phubbing terhadap relationship satisfaction. Berdasarkan hasil uji analisis regresi diketahui bahwa perilaku phubbing mampu memprediksi relationship satisfaction secara signifikan dengan nilai $F=55,921$ dan $p=0,000$ 
atau $p<0,05$. Berdasar hasil tersebut maka dapat disimpulkan bahwa hipotesis alternative $(\mathrm{Ha})$ dalam penelitian ini diterima dan Hipotesis $\mathrm{Nol}(\mathrm{H} 0)$ ditolak, yang berarti bahwa perilaku phubbing mampu memprediksi relationship satisfaction pada mahasiswa yang berpacaran di universitas bhayangkara jakarta raya.

Berdasar kepada hasil temuan, peneliti memiliki beberapa kekurangan dalam penelitian yaitu: tidak mengukur tingkat relationship satisfaction berdasarkan lamanya hubungan berpacaran dan perbedaan tingkat kepuasan antara laki laki dan perempuan serta peneliti kurang maksimal dalam menggali permasalahan dilapangan sehingga hasilnya belum sepenuhnya menggambarkan fenomena yang terjadi.

\section{Kesimpulan}

Berdasarkan hasil uji regresi linier sederhana untuk menjawab hipotesis serta melihat besarnya pengaruh perilaku phubbing terhadap relationship satisfaction, berdasarkan hasil uji regresi perilaku phubbing berpengaruh terhadap relationship satisfaction. Berdasarkan hasil uji regresi linier sederhana diketahui bahwa perilaku phubbing mampu memprediksi relationship satisfaction secara signifikan. Berdasar hasil tersebut maka dapat disimpulkan bahwa hipotesis alternative $(\mathrm{Ha})$ dalam penelitian ini diterima dan Hipotesis $\mathrm{Nol}(\mathrm{H} 0)$ ditolak, yang berarti bahwa perilaku phubbing mampu memprediksi relationship satisfaction pada mahasiswa yang berpacaran di universitas bhayangkara jakarta raya. Peneliti menyadari bahwa dalam penelitian ini sumber sumber dan referensi yang terkait dengan penelitian ini masih kurang, sehingga bagi peneliti selanjutnya hendaknya agar lebih memperbanyak lagi referensi-referensi yang terkait dengan permasalahan yang diangkat dalam penelitian. Bagi peneliti selanjutnya, sebaiknya waktu yang digunakan untuk meneliti dan mengumpulkan data lebih diperpanjang agar dapat melakukan wawancara lebih mendalam

\section{Daftar Pustaka}

Annie, A. (2020). State Of Mobile 2020.

Arnani, M. (2019). Begini Komunikasi Yang "Pas" dalam suatu hubungan. Retrieved from Kompas.Com website: https://www.kompas.com/tren/read/2019/09/13/171620165/bagaimana-komunikasi-yangpas-dalam-suatu-hubungan

Chotpitayasunondh, V., \& Douglas, K. M. (2016). How "phubbing" becomes the norm: The antecedents and consequences of snubbing via smartphone. Computers in Human Behavior, 63, 9-18. https://doi.org/https://doi.org/10.1016/j.chb.2016.05.018

Chotpitayasunondh, V., \& Douglas, K. M. (2018). The effects of "phubbing" on social interaction. Journal of Applied Social Psychology. https://doi.org/https://doi.org/10.1111/jasp.12506. Journal of Applied Social Psychology

Cizmeci, E. (2017). Disconnected, Though Satisfied: Pphubbing Behavior and Relationship Satisfaction. The Turkish Online Journal of Design, Art and Communication, 7(2), 364- 
375.

Dani, J. A., \& Mediantara, Y. (2020). Covid-19 Dan Perubahan Komunikasi Sosial. Communication Journal, 3, 94-102. https://doi.org/https://doi.org/10.30596/persepsi

Dewi, I. R. (2020). Pertumbuhan smartphone Indonesia meningkat 49 persen di Q3 2020. Retrieved from INews.ld website: https://www.inews.id/techno/gadget/pertumbuhansmartphone-indonesia-meningkat-49-persen-di-q3-2020

Di Bello, A. M., Preddy, T. M., Overup, C. S., \& Neighbors, C. (2017). nderstanding the context of romantic partner relational victimization: Links between relationship satisfaction, depressive symptoms, and alcohol-related problems. Psychology of Violence, 7(4), 543552. https://doi.org/https://doi.org/10.1037/vio0000064

Etikan, I., Musa, S. A., \& Alkassim, R. S. (2017). Perbandingan Convenience Sampling dan Purposive Sampling.

Feist, J., \& Feist, G. J. (2010). Teori Kepribadian. Jakarta: Salemba Humanika.

Hall, J. A., Baym, N. K., \& Miltner, K. M. (2014). Put Down that Phone and Talk to Me : and Similarity in Relationships. Mobile, Media \& Communication, 2(2), 134-153.

Khaddaouma, A., Shorey, R. C., Brasfield, H., Febres, J., Zapor, H., Elmquist, J., \& Stuarts, G. L. (2016). Drinking and dating: Examining the link among relationship satisfaction, hazardous drinking, and readiness-to-change in college dating relationships. Journal of College Student Development, 57(1), 34-26. https://doi.org/https://doi.org/10.1353/csd.2016.0007

Kiecolt-Glaser, J. K., \& Wilson, S. J. (2017). Lovesick: How Couples' Relationships Influence Health. Annual Review of Clinical Psychology, 13, 421-443. https://doi.org/https://doi.org/10.1146/annurev-clinpsy-032816-045111

Kurniati, G. (2015). Pengelolaan Hubungan Romantis Jarak Jauh: Studi Penetrasi Sosial Pasangan Yang Terpisah Jarak Geografis. Jurnal Komunikasi Indonesia, 4(4), 27-37.

Miller, J., \& Tedder, B. (2011). The discrepancy between expectation and reality: Satisfaction in romantic relationship. Journal of Family Psychology, 401. https://doi.org/https://psych.hanover.edu/research/Thesis12/papers/Millar Teddar Final Paper.pdf

Pawiyataningrum, K. A. (2019). Hubungan antara dyadic coping dan kepuasan relasi romantis pada dewasa awal. Retrieved from repository.usd.ac.id/36040/

Periantalo, J. (2016). Penelitian kuantitatif untuk psikologi. Yogyakarta: Pustaka Pelajar.

Pratiwi, Z. S. (2020). Phubbing sebagai fenomena budaya pop studi kasus pada mahasiswa fakultas ilmu sosial ilmu politik Universitas Andalas. Jurnal Kesehatan Dan Pelayanan Sosial, 1(1), 20-32.

Priyatno, D. (2012). Belajar Cepat Olah Data Statistik dengan SPSS. Jakarta: Andi Offset.

Rahma. (2020). Terpaksa LDR karena corona. Retrieved from Departemen Riset Dan Keilmuan website: https://Im.psikologi.ugm.ac.id/2020/06/terpaksa-Idr-karena-corona/

Retalia. (2020). Dampak intensitas penggunaan smartphone terhadap interaksi sosial. Journal 
of Education Psychology and Counseling.

Rosdiana, Y., \& Hastutiningtyas, W. R. (2020). Hubungan Perilaku Phubbing Dengan Interaksi Sosial Pada Generasi Z Mahasiswa Keperawatan Universitas Tribhuwana Tunggadewi Malang. Jurnal Kesehatan https://doi.org/https://doi.org/10.36053/mesencephalon.v6i1.194

Safitri, N., \& Arianti, M. (2019). Bentuk Pertahanan Diri dan Strategi Coping Mahasiswa Korban Kekerasan Dalam Pacaran. Prosiding Konferensi Nasional Peneliti Muda Psikologi Indonesia, 4(4), 11-22.

Santrock, J. W. (2012). Life-Span Development (Perkembangan Masa Hidup) (13th ed.). Jakarta: Erlangga.

Servies, A. (2012). Cell Phones and Couple Communication: The Impact of Mobile Device Distractions during a Dyadic Interaction.

Sugiyono, P. D. (2016). Metode Penelitian Kuantitatif, kualitatif dan R\&D. Bandung: CV Alfabeta.

Utami, E., \& Rachmawati, D. (2015). Ini jadinya jika hubungan dibangun tanpa rasa saling mengerti. Retrieved from Suara.Com website: https://www.suara.com/lifestyle/2015/11/26/074656/ini-jadinya-jika-hubungan-dibanguntanpa-rasa-saling-mengerti

Whisman, M. A., Uebelacker, L. A., \& Settles, T. D. (2010). Marital Distress and the Metabolic Syndrome: Linking Social Functioning With Physical Health. Journal of Family Psychology, 24(3), 367-370. https://doi.org/https://doi.org/10.1037/a0019547

Wima, P. (2015). Buat apa mengekang, Jika memberi dia kebebasan justru semakin menguatkan hubungan kalian. Retrieved from Hipwee.Com website: https://www.hipwee.com/hubungan/kenapa-harus-mengekang-pasangan-jikamemberinya-kebebasan-justru-membuat-hubungan-kalian-semakin-kuat-bertahan/

Yashinta. (2019). Mengenal New Media atau Media Baru. Retrieved from Kompasiana.com website:

https://www.kompasiana.com/yashintad3512/5d6250ef0d823042b52f92f2/mengenal-newmedia-atau-media-baru

Yu, R., Branje, S., Keijers, L., \& Meeus, W. H. J. (2014). Personality effects on romantic relationship quality through friendship quality: A ten-year longitudinal study in youths. PLOS ONE, 9(9). https://doi.org/https://doi.org/10.1371/journal.pone.0102078 